\title{
IGU Commission on Industrial Change UGI Commission du Changement Industriel
}

Bulletin 15 (abridged by GeoJournal)

November-Dezember 1991

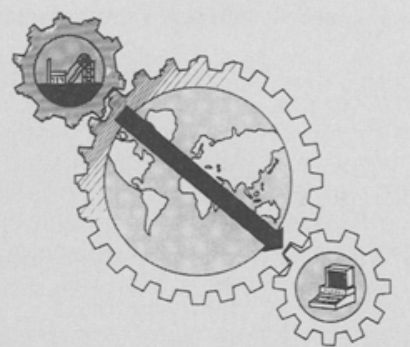

A Future Industrial Commission?

The present Commission on Industrial Change was elected at the General Assembly of the International Geographical Union in Paris in September 1984. Under the IGU Statutes, Commissions can be re-elected for one further four-Year period (as this one was in Sydney in 1988). The term of the current Commission and its Chair thus expires in August 1992.

Last year the IGU Secretariat called for proposals for new Commissions and Study Groups to be transmitted to it by 30 September 1991. At least one proposal for a new Commission focusing on industrial geography has been submitted. At its meeting during 21-24 October in Prague, Czechoslovakia, the IGU Secretariat will decide which proposals should be recommended to the National Committee (or its equivalent) of the sixty member countries with voting rights, and their votes will be recorded during the General Assembly of the IGU in Washington, 9-14 August 1992.

At this stage, it is anticipated that further details will be reported in the final Bulletin of this Commission scheduled for September/. October 1992.

\section{Residental Conference}

Orlando, Florida, 3 to 7 August

\section{Time, Space, Competition and Contemporary Industrial Change}

The 1992 Residential Conference will be held from 3 to 7 August (Monday to Friday inclusive) at the Mission Inn Resort Hotel (about $75 \mathrm{~km}$ northwest of Orlando Airport). Participants will be expected to arrive in time for dinner on Sunday, 2 August, and depart after breakfast on Saturday, 8 August.

The basic theme is intended to incorporate such topics as:

$\downarrow$ new inter-firm structures such as strategic alliances and global networks;

$\downarrow$ flexible modes of competition affecting labour, capital and inter-firm relationships;

$\downarrow$ regulatory and institutional responses to the global market place;

$\downarrow$ factors and processes behind the competitive advantage of nations, regions and localities;

$\downarrow$ dynamics of production and comsumption systems;

$\downarrow$ utilisation of information technology;

$\downarrow$ new production and consumption technologies and strategies;

$\downarrow$ the more rapid pace of innovation and shorter product-cycles.

\section{Call for Papers}

Two-page synopses of papers proposed for delivery to the 1992 Conference should be airmailed to the Commission Chair - G.J.R. Linge, Department of Human Geography, RSPacS, The Australian National University, GPO Box 4, Canberra, A.C.T. 2601, Australia (Fax 616257 1893) - by 31 January 1992. They will be considered by an international selection committee appointed for this conference. Synopses should show clear evidence that the paper is relevant to the theme of this Conference. Papers selected for presentation should not have been published, or submitted for publication, and must be given orally in English or French in 25 minutes or less. No more than 30 papers will be accepted for presentation.

\section{Further Information}

The provisional total cost per participant will be about \$ US 499 (shared accommodation) or about \$ US 860 (singel accommodation): this includes full board, and all-day excursion, and transport to and from Orlando Airport. Further information from the Local Organiser, Professor Edward J. Malecki, Department of Geography, University of Florida, Gainesville, Florida 32611, USA (Telex: 568757 UF CENTROP; Fax: 904392-3584). The number of participants will be limited to about 50. 


\section{Report on 1991 Malaysian Residential Conference}

\section{Human Resources, Development and Industrial Change}

The sixth annual residential conference of the Commission was held at the Casuarina Beach Hotel, Penang, Malaysia, from Monday 19 August to Friday 23 August. Thirty-three participants attended from eighteen countries. The conference was greatly honoured by an opening address by the Chief Minister of Penang State, Dr. Koh Tsu Koon. He outlined the government's two-pronged approach to the future industrial growth of Penang State which he summarised as 'Moving Up' and Moving Out'. The former will stress the development of human resources and the continuous upgrading of skills and manpower. This will involve not only the formal education system to provide basic skills, administrative structure and procedures, but also the harnessing of the initiatives and ingenuity of the private sector to provide a wide range of training programs to cater for the diverse and changing needs of the manufacturing sector. The second approach is to promote the distribution of more labour-intensive operations to neighbouring States; the Chief Minister also suggested that the concept of intra-national cooperation should be expanded to include new regions like Northern Sumatra and Southern Thailand.

On Monday, 19 August, the State of Penang graciously hosted a dinner for participants. The all-day exeursion on Wednesday, 21 August, began with a briefing about local industrial development at the offices of the Penang Development Corporation. This was followed by a visit to the factory of Loh Kim Teow engineering Sdn Bhd and a brief tour of the Bayan Lepas Free Trade Zone/Prai Industrial Estate. After lunch at the University Sains Malaysia, the group visited the Philips consumer electronics plant (Audio Electronics Sdn Bhd) in the Bayan Lapas Free Trade Zone where it as shown the sequence of operations from the initial assembly of micro-circuit boards through to the final assembly and testing of stereo radios and disc and casette players. The group then heard a fascinating address by Mr. Boonler Somchit, Executive Director, at the Penang Skills Development Centre, which with the assistance of Industry organises courses to enhance the technical and managerial abilities of the local labour force, thus supplementing on-the job training schemes. The day ended with a journey by the funicular railway up Penang Hill to the Bellevue Hotel where a special Malaysian-style steamboat dinner was served.

On Friday, 23 August, the Vice-Chancellot of University Sains Malaysia, Datuk Haji Musa Mohammad, hosted a Farewell Dintrer. This provided an opportunity for the participants to express their appreciation to the University for giving the Conference its imprimatur and much practical assistance. They also warmly thanked Mrs. H. Yaacob and her colleagues who ran a most efficient Secretariat, and paid special tribute to Professor Dr. Mahindar Santokh Singh (the Local Organiser) and her colleagues for all they did to make everyone so welcome.

\section{Malaysian Conference: Themes and Issues}

In an opening address Godfrey Linge put forward neglected ideas which need to be put on the research agenda. He focused on the human side of the labour factor and pointed at the ways this was being dehumanised in our seientific discussions. In addition, 1abour is constantly changing both in a qualitative and a quantitive sense, $\mathrm{e}, \mathrm{g}$. in terms of (female) participation rates or age-group composition. The analysis of 'devopment' often concentrates in its positive impacts and the possible negative consequences tend to be overlooked or neglected. Moreover, industrial change embraces a wide range of activities which influence and are influenced by manufacturing. These three sets of ideas do not belong in separate boxes but should be integrated and therefore there is a need to reconstruct our approaches and develop more lateral thinking.

The next two sessions were devoted to the role of emerging regional networks. Sergio Conti discussed this within the context of the EEC from the changes in the economy and the emergence of a post-industrial society: old networks were being revitalised. Peter de Souza pointed to the new structures of economic cooperation between the Soviet Far East and the Pacific. Also within Southeast Asia different networks gain in importance. Some are already longer established and provide the focus for new developments as discussed by Rebecca Chiu on the industrial cooperation between Southern China and Hong Kong and Martin Perry on the Singapore-RaiuJohor Baru growth triangle.

Stinilar phenomenon can be observed within China where the growing linkages between urban und rural industry were analysed by Pang Xiaomin. Structural differences in enterprise linkages between different economic systems were the focus of the study presented by Tsao Yong. This was also taken up by Paivi Oinas but orientated towards types of firms and their local relations. Also in session 12 the role of inter-enterprise cooperation in Japan and its concequences for human resource development was discussed by Atsuhiko Takenchi.

On an international level the firm is operating in a globat realm. However, the impact is felt on different scales in different ways. Richard Le Heron ilustrated this in section 4 from the perspective of human resource management in Australia and New Zealand. In section 5 Heike Bertram followed this up by discussing changes in the German automobile industry and their consequnces for sourcing and selling strategies, and John Holmes highlighted the new realities and changing labour relations between Mexico and the United States. The consequences and responses of the labour impacts of internationalisation were further developed on the basis of a paper by Mahindar Santokh Singh on the formation of local skills spaces and skills networking in Penang, and by Ayda Eraydin in the case of Turkey, In the latter paper the impact of the restructuring process formed the point of departure for the analysis of the ways in which a new division of labour emerges. Industrial change should not only be studied from the perspective of the maufacturing industry alone. In session 8 this point was taken up by Ed Malecki, who pointed at the role of culture in technological development and economic growth.

Not only the process of change but also the adjustments to change in different socio-economic settings and different levels of aggregation formed the theme of session 9 and 10 . In a presentation by Tadeusz Stryjakiewicz the problems of adaption of industry and its labour force to the new economie system in Poland was discussed, whereas Chris Rogerson pointed at possible industrialisatoin strategies in the period beyond racial Fordism in South Africa. At the level of the firm Susan McGrath demonstrated the effects of structural changes in the economy and the necessity of change for the labour relations in the Australian coal-mining industry.

During the whole ineeting there was a very lively discussion on theoretical and conceptual issues based in the papers presented and their empirical evidence which culminated in a specially programmed discussion session on Thursday morning. 